\title{
COMMENT
}

\section{The time has come to mitigate the risk of lead exposure from blood transfusions}

\author{
Jennifer Andrews ${ }^{1}$ \\ Pediatric Research (2019) 85:7-8; https://doi.org/10.1038/s41390-018-0218-2
}

Exposure to heavy metals including lead is associated with neurodevelopmental delays in neonates and children. ${ }^{1,2}$ Evidence for this toxicity has strengthened over time such that the US Centers for Disease Control and Prevention (CDC) revised their previous "blood lead level of concern" in children from $10 \mu \mathrm{g} / \mathrm{dL}$ to a reference value based on the 97.5th percentile of the National Health and Nutrition Examination Survey (NHANES) blood level distribution in children $1-5$ years old, now $5 \mu \mathrm{g} / \mathrm{dL}^{3}$ The World Health Organization (WHO) has withdrawn their previous provisional tolerable weekly intake (PTWI) of $25 \mu \mathrm{g} / \mathrm{kg} /$ week because even at lower doses long-term neurotoxicity concerns remain. ${ }^{4}$ There is no recognized safe intake level for lead in children.

In this issue of Pediatric Research, White et al. report on mean lead, mercury, and cadmium concentrations measured in 192 randomly selected packed red blood cell unit segments ( $p R B C s$ ) in their hospital's blood bank from July through September 2017. They compared mean levels of these three heavy metals in pRBCs collected from two American Red Cross regional centers to mean levels in adults assessed during the 2013-2014 NHANES. The authors found that mean lead $(1.11 \pm 0.75 \mu \mathrm{g} / \mathrm{dL})$ and cadmium $(0.49 \pm 0.46 \mu \mathrm{g} / \mathrm{L})$ concentrations were significantly higher in donor pRBCs compared to NHANES controls ( $p<0.01, p<0.001$, respectively). The mean mercury concentration $(1.01 \pm 1.45 \mu \mathrm{g} / \mathrm{L})$ was not statistically significantly higher in blood donors compared with adults assessed for NHANES $(p=0.066)$. Based on the historical threshold set for PTWI in 1996 by the WHO for safe drinking water and assumptions around absorption absent other known lead exposure, the authors find that over $14 \%$ of the 192 pRBCs measured exceeded the weekly $25 \mu \mathrm{g} / \mathrm{kg}$ limit in extremely low birthweight (ELBW) infants. ${ }^{5}$

Almost 20 years ago, Bearer et al. prospectively followed 19 premature infants $<30$ weeks' gestation during their first 4 weeks of life and measured each infant's blood lead concentration on admission, before and after 79 pRBC transfusions and at 4 weeks of age. They also measured the lead concentration in donor pRBCs. On average, each infant received $4.2 \pm 2.8$ pRBC transfusions, with the average lead dose per transfusion being $1.56 \pm$ $1.77 \mu \mathrm{g} / \mathrm{kg}$. The authors showed the rise in infant lead levels was specifically related to the pRBC transfusion such that for every microgram of lead transfused above a dose of $1.5 \mu \mathrm{g} / \mathrm{kg}$, the infants' lead level increased by $3.6 \mu \mathrm{g} / \mathrm{kg}$. Of the $79 \mathrm{pRBCs}$ transfused, 71 (90\%) exceeded the acceptable daily allowance set by the WHO in 1996, which has since been withdrawn. ${ }^{6}$
Though adult lead levels have dropped since 2000 when this initial study was published, ${ }^{3}$ several recent studies demonstrate that $\mathrm{pRBCs}$ remain a source of lead exposure to neonates. Zubairi et al. demonstrated a direct linear relationship between lead exposure from pRBC transfusions and subsequent post-transfusion blood lead level in 34 very low birth weight (VLBW) infants followed prospectively. For these 34 infants who received 126 pRBC transfusions (with an average pRBC lead level of $1.3 \mu \mathrm{g} / \mathrm{dL}$ ), for each $1 \mu \mathrm{g} / \mathrm{dL}$ increase in transfused pRBCs, the infant's posttransfusion blood level increased by $0.2 \mu \mathrm{g} / \mathrm{dL}^{7}$

Elabiad and Hook prospectively studied 37 infants with birth weights $<1000 \mathrm{~g}$ who received $322 \mathrm{pRBC}$ transfusions. All 47 units from which these 322 aliquots were made had detectable lead levels, on average $18.3 \pm 10.4 \mu \mathrm{g} / \mathrm{L}$. Of the $322 \mathrm{pRBC}$ transfusions, $134(42 \%)$ exceeded the authors' exposure reference of $0.19 \mu \mathrm{g} /$ $\mathrm{kg} /$ day to an individual neonate, based on lead intake deemed to be concerning with a population decrease of three intelligent quotient (IQ) points by the Joint Food and Agriculture/WHO Expert Committee on Food Additives. ${ }^{8}$ The authors conclude that in ELBW infants, blood transfusions remain a significant source of toxic lead exposure particularly during the first critical weeks of brain development. ${ }^{4}$

In a follow-up study, Elabiad and Christensen prospectively measured lead levels in all pRBC units transfused and lead levels in 10 neonates weighing $\leq 750 \mathrm{~g}$ at birth on days of life $1,4,5$, and 7 and lead in their urine on days of life 1, 4, and 7 . Nine infants received on average $2.9 \pm 2.5$ pRBC transfusions for a total of 19 pRBC transfusions, which contained on average $1.9 \pm 2 \mu \mathrm{g} / \mathrm{dL}$ of lead per unit. The authors found that for each $1 \mu \mathrm{g} / \mathrm{dL}$ increase in transfused pRBC lead level, the infant's blood level increased by $0.63 \mu \mathrm{g} / \mathrm{dL}$. Interestingly, urine excretion of lead decreased over time as blood lead levels increased, suggesting that excretion of lead through urine was an inefficient process in ELBW infants and that lead was retained. The authors postulate that metal excretion through stool is also probably inefficient, but their study did not include measuring lead levels in stool. ${ }^{9}$

The collective findings of these prospective studies in neonates illustrate a pressing need to screen blood for lead in the US, at minimum prior to transfusing $\mathrm{pRBCs}$ to the smallest and most high-risk neonates. The US FDA and blood collection industry's recent rapid response to the Zika epidemic demonstrates both the capability and cost society is willing to pay to ensure the safety of the US blood supply. ${ }^{10}$ Between April 2016 and April 2017, 30 cases of true positive Zika virus cases were found from screening

'Department of Pathology, Microbiology and Immunology and Pediatrics, Vanderbilt University Medical Center, Nashville, TN, USA

Correspondence: Jennifer Andrews (jennifer.andrews@vanderbilt.edu)

Received: 19 September 2018 Accepted: 1 October 2018

Published online: 23 October 2018 
over 4 million blood donations $(<0.001 \%)$ at an annual estimated cost of $\$ 137$ million. $^{11,12}$

A recent prospective study showed that screening blood for lead toxicity at a large academic tertiary care hospital is feasible. Gehrie et al. screened pRBCs from 100 random donor units, which had a mean lead concentration of $1.1 \mu \mathrm{g} / \mathrm{dL}$. Over 50 pRBCs tested (50\%) had lead concentrations $<1 \mu \mathrm{g} / \mathrm{dL}$, the authors' proposed cutoff for transfusion to pediatric patients. Notably, the authors concluded that it was "feasible to meet most if not all of the need of pediatric patients at one site with pRBCs containing $<1 \mu \mathrm{g} / \mathrm{dL}$ of lead. ${ }^{13 \text { " }}$ According to the most recent National Blood Collection and Utilization Survey report, 263,000 whole blood and pRBC units were transfused to pediatric patients, representing just $1.9 \%$ of $13,785,000$ whole blood and pRBC units transfused in the United States in 2011. ${ }^{14}$ Though imprecise given that not all these transfusions were in neonates, targeting lead testing in just a fraction of total units transfused in the United States seems possible. At a current cost of $\sim \$ 50$ to $\$ 80$ per lead test, ${ }^{13}$ the annual cost of screening pRBC units would be between $\$ 13$ and $\$ 21$ million (if one assumes all 263,000 units transfused to children were tested), just a fraction of the cost for Zika virus testing.

Bearer et al. described the economic benefit of testing pRBCs for lead in 2000 , estimating that for every $1 \mu \mathrm{g} / \mathrm{dL}$ increase in blood lead level, the resultant loss of 0.245 IQ points translated into a loss of expected lifetime market and nonmarket earnings of $\$ 5307$. Multiplying this figure by the total decrease in lead avoided from pRBC transfusion in 13 infants, the authors estimate $\$ 143,289$ saved in expected lifetime market and nonmarket earnings. ${ }^{6}$ Using the Consumer Price Index for All Urban Consumers, these saved earnings adjusted for inflation in 2018 would total $\$ 213,920,{ }^{15}$ again just in 13 infants who avoided lead toxicity $\geq 5 \mu \mathrm{g} / \mathrm{dL}$ from $\mathrm{pRBC}$ transfusion. Though the total number of neonates transfused pRBCs in the United States with toxic lead levels is currently unknown, one can imagine the tremendous cost savings if all neonates avoided loss of IQ points and subsequent lost earnings from transfused lead.

In summary, White et al. report yet another prospective study in this issue of Pediatric Research that confirms that $\mathrm{pRBC}$ remain a source of toxic lead exposure especially for our most vulnerable neonatal patients. Given the known adverse effects of lead on neurocognition, especially in developing brains, we must advocate for policy and regulations from our colleagues in the blood collection industry and our regulators in the United States, including the FDA, to mandate lead testing in pRBCs, at a minimum for those transfused to neonates. It is feasible, economically sound and with this critical mass of scientific evidence, we as pediatricians must advocate that lead level testing be performed at our local blood collection centers and/or hospital blood banks for our most at-risk patients.

\section{ACKNOWLEDGEMENTS}

The author would like to thank Dr. Garrett S. Booth for his thoughtful review of this manuscript.

\section{ADDITIONAL INFORMATION}

Competing interests: The author declares no competing interests.

Publisher's note: Springer Nature remains neutral with regard to jurisdictional claims in published maps and institutional affiliations.

\section{REFERENCES}

1. Bellinger, D., Leviton, A., Waternaux, C., Needleman, H. \& Rabinowitz, M. Longitudinal analyses of prenatal and postnatal lead exposure and early cognitive development. N. Engl. J. Med 316, 1037-1043 (1987).

2. $\mathrm{Hu}, \mathrm{H}$. et al. Fetal lead exposure at each stage of pregnancy as a predictor of infant mental development. Environ. Health Perspect. 114, 1730-1735 (2006).

3. Centers for Disease Control and Prevention. Response to Advisory Committee on Childhood Lead Poisoning Prevention Recommendations in Low Level Lead Exposure Harms Children: A Renewed Call of Primary Prevention; 16 pp., U.S. Department of Health and Human Services, Public Health Service, CDC, Atlanta, GA [updated 7 June 2012]. Available at http://www.cdc.gov/nceh/lead/ACCLPP/ CDC Response Lead Exposure Recs.pdf. Accessed 10 September 2018.

4. Elabiad, M. T. \& Hook, R. E. Lead content of blood transfusions for extremely lowbirth-weight infants. Am. J. Perinatol. 30, 765-770 (2013).

5. White, K., et al. Donor blood remains a hidden source of heavy metal exposure. Pediatr. Res. (2018).

6. Bearer, C. F., O'Riordan, M. A. \& Powers, R. Lead exposure from blood transfusion to premature infants. J. Pediatr. 137, 549-554 (2000).

7. Zubairi, H., Visintainer, P., Fleming, J., Richardson, M. \& Singh, R. Lead exposure in preterm infants receiving red blood cell transfusions. Pediatr. Res. 77, 814-818 (2015).

8. Joint Food and Agriculture Organization/World Health Organization Expert Committee on Food Additives (JECFA). 73rd meeting; Geneva; 8-17 June 2010. Available at: http://www.who.int/foodsafety/publications/chem/summary73.pdf. Accessed 10 September 2018.

9. Elabiad, M. \& Christensen, M. Changes in premature infant mercury and lead blood levels after blood transfusions. Am. J. Perinatol. 31, 863-868 (2014).

10. Bloch, E. M., Ness, P. M., Tobian, A. A. R. \& Sugarman, J. Revisiting blood safety practices given emerging data about Zika virus. N. Engl. J. Med 378, 1837-1841 (2018).

11. Pate, L. L. et al. Detection of Zika virus RNA in United States blood donations using cobas Zika on the cobas 6800/8800 Systems. Transfusion 57(Suppl S3), 26A (2017).

12. Saa, P. P. et al. Investigational detection of Zika virus RNA in U.S. blood donors. Transfusion 57(Suppl S3), 25A (2017).

13. Gehrie, E. et al. Primary prevention of pediatric lead exposure requires new approaches to transfusion screening. J. Pediatr. 163, 855-859 (2013).

14. The 2011 National Blood Collection and Utilization Survey Report, U.S. Department of Health and Human Services. Available at https://www.hhs.gov/sites/ default/files/ash/bloodsafety/2011-nbcus.pdf. Accessed 11 September 2018.

15. U.S. Inflation Calculator, Consumer Price Index for All Urban Consumers, U.S. Labor Department's Bureau of Labor Statistics. Available at https://data.bls.gov/ cgi-bin/cpicalc.pl?cost1 =143289\&year $1=200001 \&$ year2 $=201807$. Accessed 11 September 2018. 